\title{
An Overview: Distribution, Production, and Diversity of Local Landraces of Buckwheat in Nepal
}

\author{
Dol Raj Luitel, ${ }^{1,2}$ Mohan Siwakoti, ${ }^{1}$ Pramod Kumar Jha, \\ Ajay Kumar Jha, ${ }^{3}$ and Nir Krakauer ${ }^{4}$ \\ ${ }^{1}$ Central Department of Botany, Tribhuvan University, Kirtipur, Kathmandu, Nepal \\ ${ }^{2}$ Department of Plant Resources, Ministry of Forests and Soil Conservation, Thapathali, Kathmandu, Nepal \\ ${ }^{3}$ Institute for Global Agriculture and Technology Transfer (IGATT), Fort Collins, CO, USA \\ ${ }^{4}$ City College, City University of New York, New York, NY, USA \\ Correspondence should be addressed to Dol Raj Luitel; luiteldr2@gmail.com
}

Received 20 July 2017; Accepted 5 September 2017; Published 15 October 2017

Academic Editor: Tibor Janda

Copyright (C) 2017 Dol Raj Luitel et al. This is an open access article distributed under the Creative Commons Attribution License, which permits unrestricted use, distribution, and reproduction in any medium, provided the original work is properly cited.

\begin{abstract}
Buckwheat is a sixth staple food crop after rice, wheat, maize, finger millet, and barley in Nepal. It is considered as an alternate cereal and poor man's crop, representing an important food supply in remote places of Himalayas. It is the best crop in higher altitude in terms of adaptation to different climatic variables and easily fitted to different cropping patterns due to short duration. It is cultivated on marginal land in 61 out of 75 districts of Nepal from some $60 \mathrm{~m}$ to $4500 \mathrm{~m}$ asl, especially hilly and mountain districts like Rukum, Rolpa, Jajarkot, Dolpa, Humla, Jumla, Kalikot, Kavre, Dolakha, and Okhaldhunga. Sweet buckwheat varieties are generally grown in midhill and Terai but Tartary buckwheat varieties are grown in higher altitude. There are altogether 19 local landraces of sweat buckwheat and 37 for Tartary buckwheat listed from Nepal. The largest producers are China, USA, and Russia and Japan is principal user of global buckwheat grown in the world. In Nepal, it is cultivated in 10510 ha area with production of $10355 \mathrm{t} / \mathrm{yr}$ and yield of $0.983 \mathrm{t} / \mathrm{ha}$. It has also medicinal value used in different forms including all its parts so the demand of buckwheat is increasing.
\end{abstract}

\section{Introduction}

Nepal $\left(26^{\circ}-31^{\circ} \mathrm{N}\right.$ latitudes to $80^{\circ}-89^{\circ} \mathrm{E}$ longitudes) is a landlocked country dominated by huge mountains with varied climate and topography, orography within about $240 \mathrm{Km}$ north-south. The climate ranges from tropical to temperate and alpine due to its topography and elevation, Figure 1.

Agricultural sectors contribute about $36 \%$ to National Gross Domestic product (GDP) and sixty-five percentage of total population still depends on agriculture in Nepal [1]. The agricultural lands are diverse in different physiographic regions. Mountain and high Himalaya has difficult sloping land and topography where people depend only on agriculture for their livelihood [2]. There are 125 ethnic communities residing in various regions in Nepal having their own system of culture and agricultural practices [1]. The major components of agriculture are cereals, legumes, cash crops, fruits, vegetables, and livestock. Cereal crops include paddy, wheat, maize, finger millet, buckwheat, barley, naked barley, Chino (Proso millet), and Kaguno (Foxtail millet). Farmers commonly prefer those crop varieties that produce high yield in low input, can tolerate stresses, need less care, can be grown in diverse agroclimatic condition, possess balance nutrients, and have good market prices.

Buckwheat is one of the best crops in higher altitude in terms of adaptation to climatic variables, water stress regimes, unfertile soil, and freezing temperature and is easily fitted to different cropping pattern due to short life cycle $[3,4]$.

Taxonomy. Fagopyrum esculentum Moench (sweet buckwheat) and Fagopyrum tataricum (L.) Gaertn. (bitter buckwheat) belong to family Polygonaceae. Globally 18 species are known to be the members of genus Fagopyrum including two cultivated species Fagopyrum esculentum and F. tataricum [5].

Synonym. F. esculentum subsp. ancestralis Ohnishi is a synonym for sweet buckwheat; Polygonum tataricum L., F. suffruticosum F. Schmidt., F. dentatum Moench, Fagopyrum 


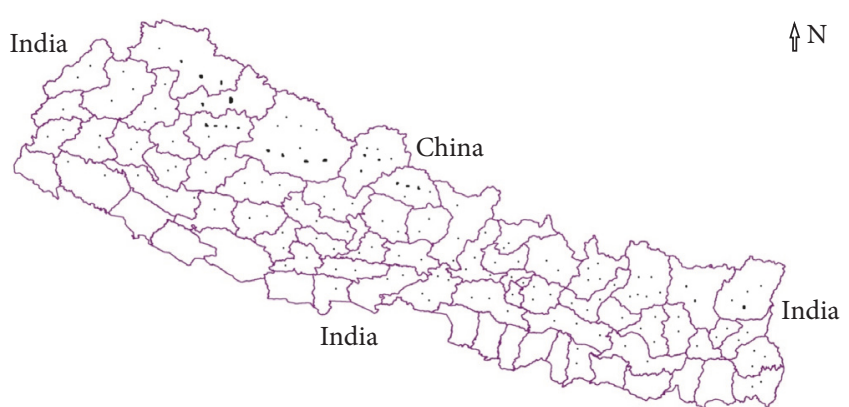

FIGURE 1: Distribution of cultivated buckwheat in districts of Nepal.

rotundatum Bab., and F. subdentatum Gilib. are synonyms for bitter buckwheat [6].

Common Names. The following is a list of the common names: sweet buckwheat or common buckwheat, Tartary buckwheat or bitter buckwheat (English), Mithe Phaper for common buckwheat, Tite Phaper for Tartary buckwheat (Nepali), er chi for common buckwheat, er $k a$ for Tartary buckwheat (Chinese), Ogal for common buckwheat, Phaper for Tartary buckwheat (India), Jare for common and bjo for Tartary buckwheat (Bhutan), and Soba in Japan [6].

In Nepal, buckwheat cultivation ranges from $60 \mathrm{~m}$ in Terai to $4500 \mathrm{~m}$ above sea level (asl.) $[4,5,7,8]$. F. esculentum is generally grown in lower altitude (Terai and mid-hills) but in higher altitude F. esculentum is replaced with F. tataricum in different cropping pattern $[4,9,10]$. It is cultivated in 61 out of 75 districts of Nepal Figure 1 [4]. Buckwheat varieties are summer crop in hill (high altitude $>1700 \mathrm{~m}$ asl), autumn and spring crop in mid-hills (600-1700 $\mathrm{m}$ asl), and winter crop in Terai $[10,11]$. However, all seasons (summer, autumn, winter, and spring) are suitable to cultivate buckwheat in different agroecological zones of Nepal.

It has been occupying an important place in the Nepalese agriculture system and contributing greatly in food supply especially remote places in Himalayas, though it is popularly considered as pseudocereals, poor man's crop, and underexploited and neglected crops in Nepal [12]. It has been cultivated in almost all parts of Nepal mostly at high altitude of western and mid-western regions. It prefers to grow best in cool, moist climatic condition though it is sensitive to frost, high temperature, high speed wind, and drought. These stresses to buckwheat crop critically reduced yield when they occur during flowering periods. It matures within 10-12 weeks of plantation that is essential in high Himalayan region of Nepal where it is favorable for cropping duration to be short. Buckwheat is the sixth staple food crop after rice, wheat, maize, finger millet, and barley in terms of cultivation area (10510 ha.), production (10355 t/yr), yield (983 kg/ha.), and uses in Nepal [13].

The aim of present paper is to attempt to augment and update the available information on buckwheat crop from Nepal based upon literature, web-based information, proceedings, annual reports of Ministry of Agriculture Development, Nepal Agricultural Research Council (NARC), and Department of Agriculture in Nepal.

\section{Biology of Buckwheat Plants}

2.1. Fagopyrum esculentum Moench. It is an annual herbaceous plant with free branches, reddish stem produces sucker for adaptation in its existing environment, reaching up to the height of $1.5 \mathrm{~m}$. It has deep rooted branched taproot system. Leaf is simple and petiolate, leaf blade is ovatetriangular, $2-8 \mathrm{~cm}$ long, and tip acuminate, leaf base is cordate or hastate, and upper leaves are small and sessile. Corymbose or paniculate cyme type of inflorescence is either terminal or auxiliary position. Each inflorescence consists of 7-9 small flowers, white, pink, or yellow in colour, and flowers are heteromorphous in nature. Pedicel is $2-3 \mathrm{~mm}$ long and articulate; perianth is $3 \mathrm{~mm}$ long; 8 nectaries are yellow, alternating with stamens, being heterostyly; stigma is capitate. Achene is triquetrous, acute angle, longer than $5 \mathrm{~mm}$, more than twice the length of the persistent perianth, brown or black-brown, and lucid [14]. It has two types of flowers, that is, pin and thrum flowers cross-pollinating type of fertilization [4]. Seeds are fully matured within 35-45 days after pollination but depend upon the temperature [15]; seeds are generally triangular but vary with varieties. Seeds hull density is less than water that makes easy to remove from seeds [16].

2.2. Fagopyrum tataricum (L.) Gaertn. Herbaceous plant is characterized with colourful branches or unbranched stem reaching up to $1 \mathrm{~m}$, branched taproot system, petiolated leaves, triangular leaf blade with the length being almost equal with width, $2-8 \mathrm{~cm}$, and cordate or hastate leaf bases. Inflorescences are dense spicate or corymbose. Flowers are yellow-green, $2.5 \mathrm{~mm}$ in diameter, pedicels are nonparticulate; perianth is $2 \mathrm{~mm}$ long; 8 nectaries are yellow, alternating with stamens, being homostyly, that is, self-pollinated flowers; stigmas are capitate. Triquetrous achene is about $5 \mathrm{~mm}$ long, exserting more than twice the length of the persistent perianth, with three deep grooves, and the angles are rounded, except at the tip. Flowers are homomorphic, selffertile, and cleistogamous with pollination occurring before the flower opens [14].

\section{Distribution}

The cultivated species of buckwheat is assumed to be native to temperate east Asia, particularly eastern site of Himalayas and southwestern China $[14,17,18]$. The exact place of origin of common buckwheat is considered as Yunnan province and in between Yunnan and Sichuan provinces of China [19]. Buckwheat was cultivated nearly 5000-6000 years ago in China and it entered Europe through Russia and spread to North America through immigrants [14].

Buckwheat is cultivated in hilly areas in Europe (also in lowlands), east Asia, and the Himalayan region. China is the biggest producer and exporter of buckwheat followed by USSR, and Japan is a principal importer of buckwheat 
TABLE 1: Local names of common and bitter buckwheat in Nepal.

\begin{tabular}{lll}
\hline SN & \multicolumn{1}{c}{ Type of buckwheat (local landraces) } \\
\hline 1 & Common (sweet) buckwheat & Bitter (Tartary) buckwheat \\
\hline & Oule, Barkhe, Bharule, Bhadre, Bhalu, Tite, Jhoumle, \\
& Chendrung, Ghode, Ghabre, Gulio, Jhusile, Kalo & Chiniya, Chuchche, Dalle, Dhahasur, Dhau, Dhesu, \\
& Madane, Mithe, Mithi, Ogale, Seto, Seychun, & Dhop, Ghamre, Gharelu, Gore, Jamdalo, Jhaumre, Kalo \\
& Sathiya, Seyekar, Thulo, Tote Phaper & tite, spangre, Tabre, Tan, Tar, Tasung, Techhung, Tensya \\
& Teta, Thou, Thinkunde tite, Tuchi, Tuchi tite Phaper \\
\hline
\end{tabular}

up to 2000 [20], but the scenario has changed, and USA became main exporter and Japan remains a major importer of American buckwheat although China, Russia, and Canada are leading sources of buckwheat flour in 2012 [21]. In Nepal, nowadays, the demand of buckwheat is increasing due to its multiple uses [8].

Buckwheat is a pseudocereal/minor food, has a short duration, a cash crop but it is one of the major staple food crops of high mountain people of Nepal. It is commonly grown in hilly and mountain regions especially in Rukum, Rolpa, Jajarkot, Dolpa, Kavre, Dolakha, Okhaldhunga, Mustang, Solukhumbu, and Taplejung districts regularly since time immemorial. But recently it has been grown in some Terai districts like Chitwan, Jhapa, and Nawalparasi for commercial purposes especially for green vegetable which has very high demand due to rutin contents (farmers interview). Every family grows Tartary buckwheat in upper Mustang and Dolpa districts and diversity of buckwheat is very high in Manang, Dolpa, Mustang, Jumla, and Solukhumbu [4, 22]. Bitter buckwheat is grown in marginal land in higher altitudes. It can withstand the poor, infertile, and acidic soils, nutrients, moistures, and heat stress with wider adaptability [14] which is prevalent to hilly area of Nepal, as shown in Figure 1. These unique characteristics of buckwheat show a great potential crop in future in food-deficit areas like high mountains which has high risk of climate change impact.

Buckwheat is drought-tolerant crop and requires approximately $100 \mathrm{~mm}$ rain for its whole growth period [23]. In midhills, the cultivation area of buckwheat may be increased if seedlings are insufficient and/or if the land is fallow due to poor fertility [24]. Buckwheat is short duration crop but its flowering period is more than 30 days [25] which is much useful to beekeepers as this yields quality honey.

\section{Diversity of Local Landraces of Buckwheat in Nepal}

So far five species of Fagopyrum (buckwheat), namely, $F$. esculentum subsp. esculentum, F. tataricum subsp. tataricum, F. tataricum subsp. potanini, $F$. tataricum subsp. annum, $F$. cymosum, F. gracilipes, and F. megacarpum, have been reported from Karnali zone [26] with the local names of following buckwheat landraces including crop calendar and productivity from western Nepal.

Mithe Phaper, local chuchche, Local Lekhari, Bhate, ACC\#2223 (recommended variety by NARC), Dalle, Kalo, Barule, Takule, Tilkunde, Tote, Ghode, and Tite Phaper are the names of local landraces recorded from Karnali zone and seeding time varies from Jestha, Ashad, and Srawan months and harvesting time from Bhadra, Aswin, and Kartik months, respectively (Table 1). The productivity of these varieties varies from district to districts and also depends upon the type of local varieties. Joshi et al. (2014) recorded from $0.90 \mathrm{t} / \mathrm{ha}$ (Jumla) lowest to $1.96 \mathrm{t} / \mathrm{ha}$ (Mugu) highest production in that year within five districts (Jumla, Kalikot, Dolpa, Humla, and Mugu) of Karnali zone.

Local landraces of buckwheat from Jumla districts of Karnali zone from Nepal include Barule, Bharule, Chuchche, Chode, Kalo, Mithe, Seto, Tilkhude, Tite, and Tote Phaper [27]. However, Rana et al. (2000) compiled six local landraces of buckwheat from Talium Village Development Committee (VDC) of the same district as Batule, Bharule, Mithe, Murali, Tilkhunde, and Tite Phaper. Bharule, Mithe, Tilkhude, and Tite Phaper are included on red list due to vulnerability of their conservation (Table 1) [28].

Joshi et al. (2014) compiled main morphological characters of some preferred local landraces of buckwheat based on liked or disliked traits by farmers in the Karnali zone as follows:

(1) Mithe Phapar having red stem and leaf, tall plant with white flower and shiny black triangular large seed are tasty, thick husk, lodging resistance, and good for dizziness disease but farmers dislike their low grain yield straw which is not good for livestock.

(2) Barule Phaper having medium plant and leaves size and seeds without pointing are of high yielding, short duration variety, leaf useful for vegetables, more branching, and more flour yield, do not need of intercultural operations, are useful for livestock, and are good for pregnant livestock; those are the liked traits, but bitterness, flour that come out from seeds when rainfall occurs after maturity, and difficulty to grind when eating more which can create swelling problem are disliked traits.

(3) Chuchche Phaper, tall pant with triangular leaf of low branching with long triangular seeds, are liked by farmers due to its low cost of intercultural operations, leaves that are useful for fresh and dry vegetables, high yield, early maturity, usefulness for cough, jaundice, and diabetes diseases, low weed problems, and usefulness for sick animals and animals during bleeding but they are disliked due to their bitterness, causing headache, turning eye yellow, and swelling the body 


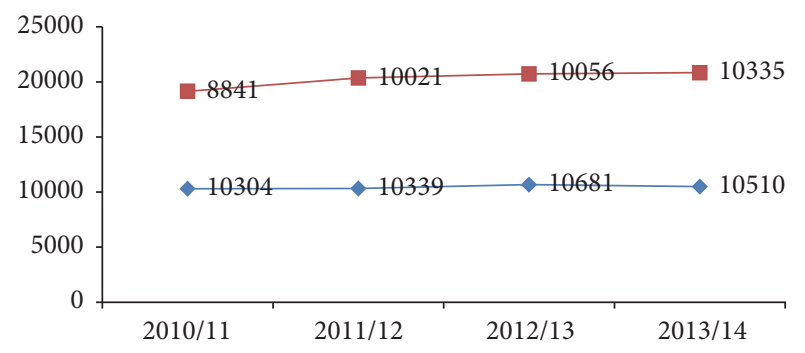

FIgURE 2: Cultivation area and production of buckwheat in Nepal from 2010 to 2014.

when eating more, no seed set in case of high moisture and fertile soil, and lodging problem in fertile soil.

Joshi and Ghimire (2015) have compiled the local names of landraces of buckwheat from Nepal as in Table 1.

\section{Production}

There is a report of country-wise production of buckwheat: higher producers are Russia $(833,936 \mathrm{t}$.) followed by China (733,000 t.), Kazakhstan (276840 t.), and Nepal (10056 t.) and Slovakia (68t.), Republic of Moldova (40 t.), and Kyrgyzstan (25 t.) are lower producers in each year [29].

Grain yield and landraces varieties richness of Tartary buckwheat in Nepal are higher than that of common buckwheat but farmer less prefer the Tartary buckwheat one because of more bitterness and difficulty in producing flour after dehulling [26]. The production of bitter buckwheat is recorded more than common buckwheat due to selfpollinating nature [30].

According to Ministry of Agricultural Development, Nepal cultivates the buckwheat in 10510 ha. area with production of $10355 \mathrm{t} / \mathrm{yr}$ and yield of $0.983 \mathrm{t} / \mathrm{ha}$ [13]. The trend of production and yield of buckwheat in Nepal is slightly changed from 2010 to $2014 \mathrm{AD}$ (Figures 2 and 3). This production of buckwheat is unable to meet the country demand. From the last 10 months (September, 2015-July, 2016) records showed that 2548 tons of buckwheat were imported from various countries with worth of about 67 US dollars in Nepal [31].

Productivity of F. esculentum is highly variable in global. It is recorded as $0.55 \mathrm{t} / \mathrm{ha}$ in Nepal, $3.0 \mathrm{t} / \mathrm{ha}$ in USSR, and $0.89 \mathrm{t} / \mathrm{ha}$ in the world. Productivity of this crop depends on numerous factors like site specificity, quality of seed, time of seed sowing, and so forth [4]. The production of buckwheat in five districts of Karnali zone was recorded and it found that it was highest in Mugu district with $982 \mathrm{t} / \mathrm{ha}$., followed by Humla, Dolpa, Kalikot, and Jumla districts, respectively, and average production and yield in Karnali zone (Pocket area of buckwheat in Nepal) were $377 \mathrm{t} / \mathrm{ha}$. and $1.082 \mathrm{t} / \mathrm{ha}$, respectively [26].

\section{Growth Value of Buckwheat}

Buckwheat is a multipurpose crop and has been cultivated for its uses as staple food, animal feed, vegetable, soup,

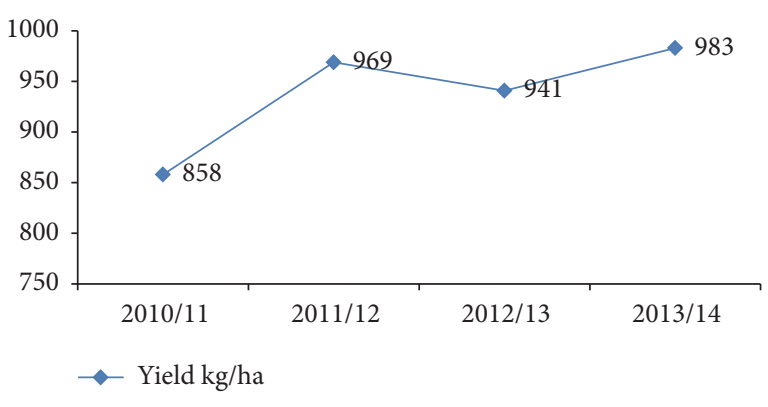

FIgURE 3: Yield of buckwheat in Nepal from 2010 to 2014.

beverage, and medicine [32]. All parts of buckwheat plants are used in varieties of ways. The leaf produced rutin important pharmaceutical product which is used to brew tea used to treat hypertonia; flowers which bloom about one month produce good quality nectar for honey; grain is the staple food; hulls of grain are used to make pillows; straw is good source feed for livestock; and green plants are used as green manures [18].

There is a list of 34 food items prepared from buckwheat in Nepal such as dhindo (thick porridge), roti (bread), momo (Chinese pancake), lagar (very thick bread), dheshu (thicker than lagar), fresh vegetables, dried vegetables, Kancho pitho (raw flour), chhyang or jaand (local beer), raksi (alcohol), salad (leaves), pickle (fresh and dry leaves), soup, ryale roti, Noodle, sel roti, bhat (rice), sausage, dorpa dal, tea, vinegar, jam, macaroni, biscuit, cakes, mithai (sweet), haluwa, puri, puwa, bhuteko Phapar (roasted grain), satu, phuraula, porridge, and pakauda. Nepalese mountain people prefer dhindo than other items because of its specific taste [4].

Common buckwheat is mostly used as bread pancake attractive item to the tourist in the tracking root of Mustang. Thick porridge prepared by mixing the flour of bitter buckwheat with Uwa (Oat) or finger millet in $1: 3$ ratio is common food of poor people in hilly area. Buckwheat has high nutrition because of balance amino acids and minerals [33] as well as free from cholesterol [34]; nowadays, it is a preferred diet in urban areas. Both buckwheat species have pharmaceutical value; the food of buckwheat has a preventive action on leg oedema [35], high blood pressure and cholesterol, and cardiovascular disease [36]. Major component of buckwheat is rutin, which is higher in bitter buckwheat than in sweet one due to the high nutrients and pharmaceutical value; Nepal has a great scope to export the buckwheat. Paste of Tartary buckwheat's flour is applied for treating wounds and fire burn, and its semicooked flour is used orally to cure cold, cough, jaundice, and fever; fresh flour is good for dandruff treatment as well as for stopping hair fall; flour paste is used in pimples and skin scratches; Tartary buckwheat flour drained water after dipping overnight is used for epilepsy; tender, twigs, and leaves of wild buckwheat is used in dysentery, pneumonia, and cholera and reduces the effect of poison; soaked flour is useful for internal worms [26]. Buckwheat flour is given to the sick goat and sheep. Common buckwheat is also preferred by local people during the fasting on the religious occasions $[4,37]$ 


\section{Conclusion}

The agricultural land of Nepal is very diverse due to varied physiography. The cropping pattern is varied in different region of Nepal; it also depends on elevation, culture, and agriculture practices of ethnic communities. Sixty-five percentage of total population still depend on agriculture and contributed 36\% for National GDP.

Buckwheat is native crop of temperate east Asia, that is, eastern site of Himalaya and southwestern China. It was introduced to Europe and American countries through immigrants. China, Russia, and USA are major producers and exporters of buckwheat and Japan is the main importer. Buckwheat is one of the major crops in high mountain of Nepal and cultivated in 61 out of 75 districts ranging from $60 \mathrm{~m}$ to $4500 \mathrm{~m}$ altitude, especially Rukum, Rolpa, Jajarkot, Dolakha, Solukhumbu, Kalikot, Kavre, and Okhaldhunga districts as well in the districts of Karnali zones of western Nepal. It is summer crop in hill (high altitude $>1700 \mathrm{~m}$ asl), autumn and spring crop in mid-hills (600-1700 m asl), and winter crop in Terai.

To date, five species of Fagopyrum (buckwheat), namely, F. esculentum, F. tataricum, F. cymosum, F. gracilipes, and F. megacarpum, have been reported from Nepal [4]. Buckwheat is multiple useful crop plant with medicinal value and all its parts (roots, stem, leaves, flower, fruits, and flour) are used to care various alignments (diseases) locally in traditional healthcare system. The demand of buckwheat is increasing nowadays due to its multiple uses.

\section{Conflicts of Interest}

The authors declare that they have no conflicts of interest.

\section{Acknowledgments}

The authors acknowledge the USAID IPM Project, for financial support. The authors acknowledge Central Department of Botany, TU, for providing lab facilities, and also thank Dr. Bal Krishna Joshi, senior scientist of National GeneBank, Khumaltar, for his suggestions and literature support as well as encouragement for this work.

\section{References}

[1] CBS, "National Population and Housing Census 2011 (National Report). Kathmandu, Nepal: Central Bureau of Statistics", Government of Nepal, 2012.

[2] T. R. Chaulagain, "Review of sustainability of average Nepalese subsistence farm in mid hills of Nepal," The Journal of Agriculture and Environment, vol. 15, pp. 139-148, 2014.

[3] B. K. Baniya, M. L. Baidya, D. R. Sharma, D. M. S. Dongol, I. Paudel, and H. P. Bimb, "Study of Nepalese titebuckwheat landraces at diverse agro-ecological regions of Nepal," in Research and Development on buckwheat: An Important yet a Neglected Crop in Nepal. Proc. National Workshop, H. P. Bimb and B. K. Joshi, Eds., Biotechnology Unit-NARC, Khumaltar, Nepal, 2001.
[4] B. K. Joshi, "Buckwheat genetic resources: status and prospects in Nepal," Agriculture Development Journal, vol. 5, pp. 13-30, 2008.

[5] T. Ohsaki, S. Fukuoka, H. P. Bimb, B. K. Baniya, Y. Yasui, and O. Ohnishi, "Phylogenetic analysis of the genus Fagopyrum (Polygonaceae), including the Nepali species F. megacarpum, based on nucleotide sequence of the $\mathrm{rbcL}-\mathrm{accD}$ region in chloroplast DNA," Fagopyrum, vol. 18, pp. 9-14, 2001.

[6] Plants name, http://www.theplantlist.org/.

[7] K. Baral, K. B. Koirala, S. Subedi et al., "Varietal Investigation on Buckwheat under different Agro-ecological zones of Nepal," in Proceeding of the 27th National Summer Crops Workshop, vol. 2, Nepal Agriculture Research Council, Khumaltar, Nepal, April 2013.

[8] B. K. Joshi and K. H. Ghimire, Phaper kheti ra Biu utpadan prabidhi (in Nepali language) Information Letter series, Local crop project. Vol-1, Li-bird National gene bank, Department of Agriculture and Biodiversity International, Nepal, 2015.

[9] O. Ohnishi, "Population genetics of cultivated common buckwheat, Fagopyrum esculentum Moench. VII. allozyme variability in Japan, Korea, and China," the japanese journal of genetics, vol. 63 , no. 6 , pp. 507-522, 1988.

[10] S. B. BK, “Buckwheat Varietal Investigation Report 1998/99,” in Proceedings of the Hill Crops Workshop of Summer and Winter Crops Workshop Finger Millet, Buckwheat and Barley, Nepal Agriculture Research Council (NARC), Khumaltar, Nepal, March 2000.

[11] K. Atreya and P. R. Shakya, "Response of Buckwheat (Fagopyrum esculentum) to different level of Nutients 1998-1999 . in. Hill crops workshop proceedings of summer and winter crops workshop finger millet, buckwheat and barley," in Proceedings of the Lumle kaski and, Parwanipur, Bara, Nepal, 2000.

[12] B. K. Baniya, "Present status of buckwheat genetic resources in Nepal," Current Advances in Buckwheat Research, pp. 47-53, 1995.

[13] MoAD, Statistical Information on Nepalese Agriculture (2070/071). Agri-Business Promotion and Statistics Division, Agri statistics Section, Ministry of Agricultural Development, Government of Nepal, 2014.

[14] C. G. Campbell, Buckwheat. Fagopyrum esculentumMoench. Promoting the conservation and use of underutilized and neglected crops. Institute of Plant Genetics and Crop Plant Research, Gatersleben/International Plant Genetic Resources Institute, Rome, Italy, 1997.

[15] A. L. Jacquemart, V. Cawoy, J. M. Kinet, J. F. Ledent, and M. Quinet, "Is buckwheat (Fagopyrum esculentum Moench) still a valuable crop today?" The European Journal of Plant Science and Biotechnology, vol. 6, no. 2, pp. 1-10, 2012.

[16] S.-Q. Li and Q. H. Zhang, "Advances in the development of functional foods from buckwheat," Critical Reviews in Food Science and Nutrition, vol. 41, no. 6, pp. 451-464, 2001.

[17] O. Ohnishi and M. Tomiyoshi, "Distribution of cultivated and wild buckwheat species in the $\mathrm{Nu}$ river valley of southwestern China," Fagopyrum, vol. 22, pp. 1-5, 2005.

[18] I. Gondola and P. P. Papp, Origin, geographical distribution and phylogenic relationships of common buckwheat (Fagopyrum esculentum Moench.)“. The European Journal of Plant Science and Biotechnology. Global Science Book, 2010.

[19] O. Ohnishi, Diversity of new Fagopyrum species and its implication for the studies of evolution of Fagopyrum and of the origin of cultivated buckwheat". Cited in Gondola and Papp, 2010. 
Origin, geographical distribution and phylogenic relationships of common buckwheat (Fagopyrum esculentum Moench.). The European Journal of Plant Science and Biotechnology. Global Science Book, 1995.

[20] K. Sherchand, "A global buckwheat trading," in Research and Development on Buckwheat: An Important yet a Neglected Crop in Nepal. Proc. National workshop, P. H. Bimb and B. K. Joshi, Eds., Biotechnology Unit -NARC, Kathmandu, Nepal, September 2001.

[21] FAOSTAT Data Online Database, 2012, http://faostat.fao.org.

[22] M. L. Vaidya, B. K. Baniya, H. P. Bimb, S. R. Upadhyay, D. Sharma, and D. Dongol, On-farm conservation of bitter buckwheat in the mountain of Nepal: A feasibility study. Agricultural Botany Division, Nepal AgriculturalResearch Council, Lalitpur, Nepal, 1999.

[23] B. K. Baniya, "Buckwheat Training report," in Nepal Agriculture Research Council, Hill crops Research Program, Kabre, Dolakha, Nepal, 1993.

[24] D. B. Gharti, "Summer Hill crops Report," in Nepal Agriculture Research Council, Hill crops Research Program, Kabre, Dolakha, Nepal, 1996.

[25] B. P. Rajbhandari, Buckwheat in the land of Everest. Himalayan College of Agricultural Science and Technology (HICAST), Kathmandu, Nepal, 2010.

[26] B. K. Joshi, M. L. Vaidya, H. K. Upreti et al., "Rice and Buckwheat genetic resources in Karnali zone," Agriculture Development Journal, vol. 10, pp. 1-22, 2014.

[27] C. L. Poudel, P. R. Tiwari, J. D. Neupane, and D. P. Devkota, Strengthening the scientific basis for in-situ conservation of agrobiodiversity: Findings of site selection in Jumla, Nepal, NP working Paper No 3/98. NARC/LIBIRD/IPGRI., 1998.

[28] R. B. Rana, C. L. Tiwari, P. R. Gauchan et al., In situ crop conservation: Findings of agro-ecological, crop-diversity and socio-economicbaseline survey of Talium ecosite, Jumla, Nepal, NP working Paper No 3/2000. Narc/Libird, Nepal/Ipgri, Rome, Italy, 2000.

[29] Global Buckwheat production, https://www.wikipedia.org/.

[30] B. K. Bania, Buckwheat in Nepal. Paper presented at the 4th International Symposium on Buckwheat, Orel, USSR, July 1015, 1989. Cited in: Neupane, 2011 Participatory evaluation and promotion of cereals and grain legumes for enhancing food security at Bajura district, Nepal. Agronomy Journal of Nepal, 1990.

[31] News Paper daily, (June-20, Kantipur daily News paper, Nepal), 2016.

[32] S. Dhakal, P. Regmi, R. Thapa, S. Sah, and D. Khatri-Chhetri, "Resource Use Efficiency of Mustard Production in Chitwan District of Nepal," International Journal of Applied Sciences and Biotechnology, vol. 3, no. 4, p. 604, 2015.

[33] B. O. Eggum, I. Kreft, and B. Javornik, "Chemical composition and protein quality of buckwheat (Fagopyrum esculentum Moench)," Qualitas Plantarum Plant Foods for Human Nutrition, vol. 30, no. 3-4, pp. 175-179, 1980.

[34] M. L. P. De Francischi, J. M. Salgado, and R. F. F. Leitão, "Chemical, nutritional and technological characteristics of buckwheat and non-prolamine buckwheat flours in comparison of wheat flour," Plant Foods for Human Nutrition, vol. 46, no. 4, pp. 323329, 1994.

[35] N. Ihme, H. Kiesewetter, F. Jung et al., "Leg oedema protection from a buckwheat herb tea in patients with chronic venous insufficiency: A single-centre, randomised, doubleblind, placebo controlled clinical trial," European Journal of Clinical Pharmacology, vol. 50, no. 6, pp. 443-447, 1996.

[36] I. He, M. J. Klag, P. K. Whelton et al., "Oat and buckwheat intake and cardiovascular disease risk factors in an ethnic minority of China," American Jounal of Clinical Nutrition, vol. 61, pp. 366372, 1995.

[37] B. K. Baniya, "Buckwheat research in Nepal: an overview," in Research and Development on buckwheat: An Important yet a Neglected Crop in Nepal. Proc. National Workshop, P. H. Bimb and B. K. Joshi, Eds., Biotechnology Unit-NARC, Khumaltar, Nepal, September 2001. 


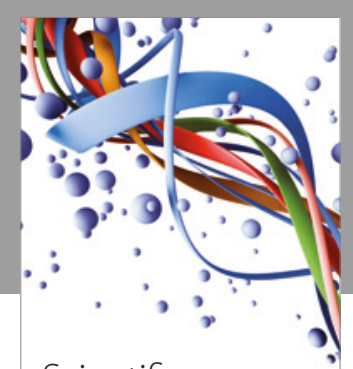

Scientifica
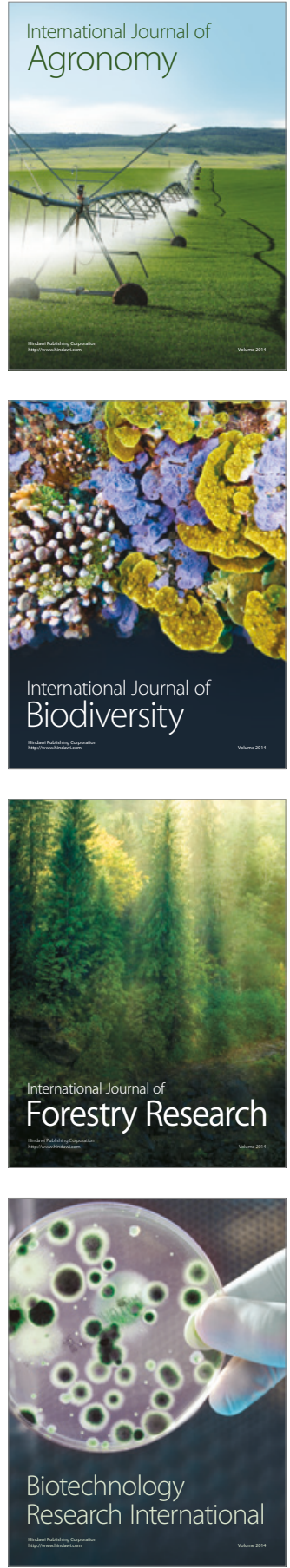
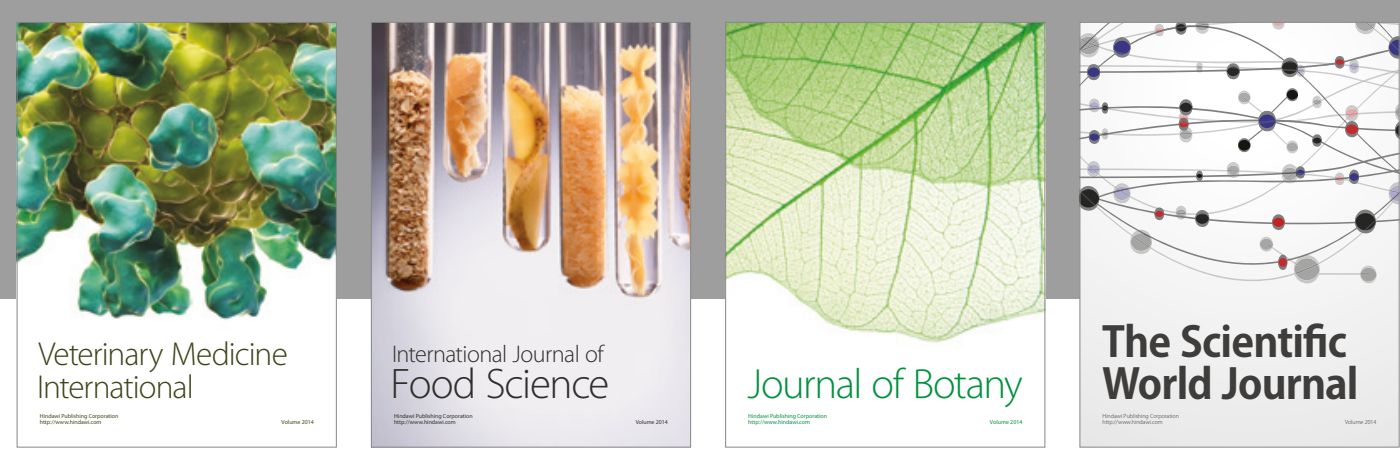

The Scientific

\section{World Journal}

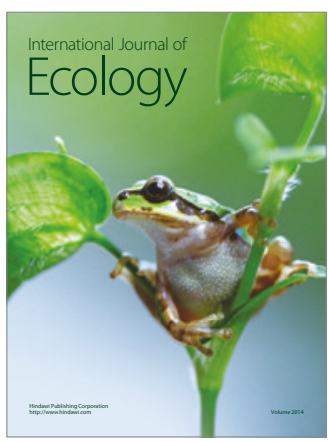

\section{Hindawi}

Submit your manuscripts at

https://www.hindawi.com
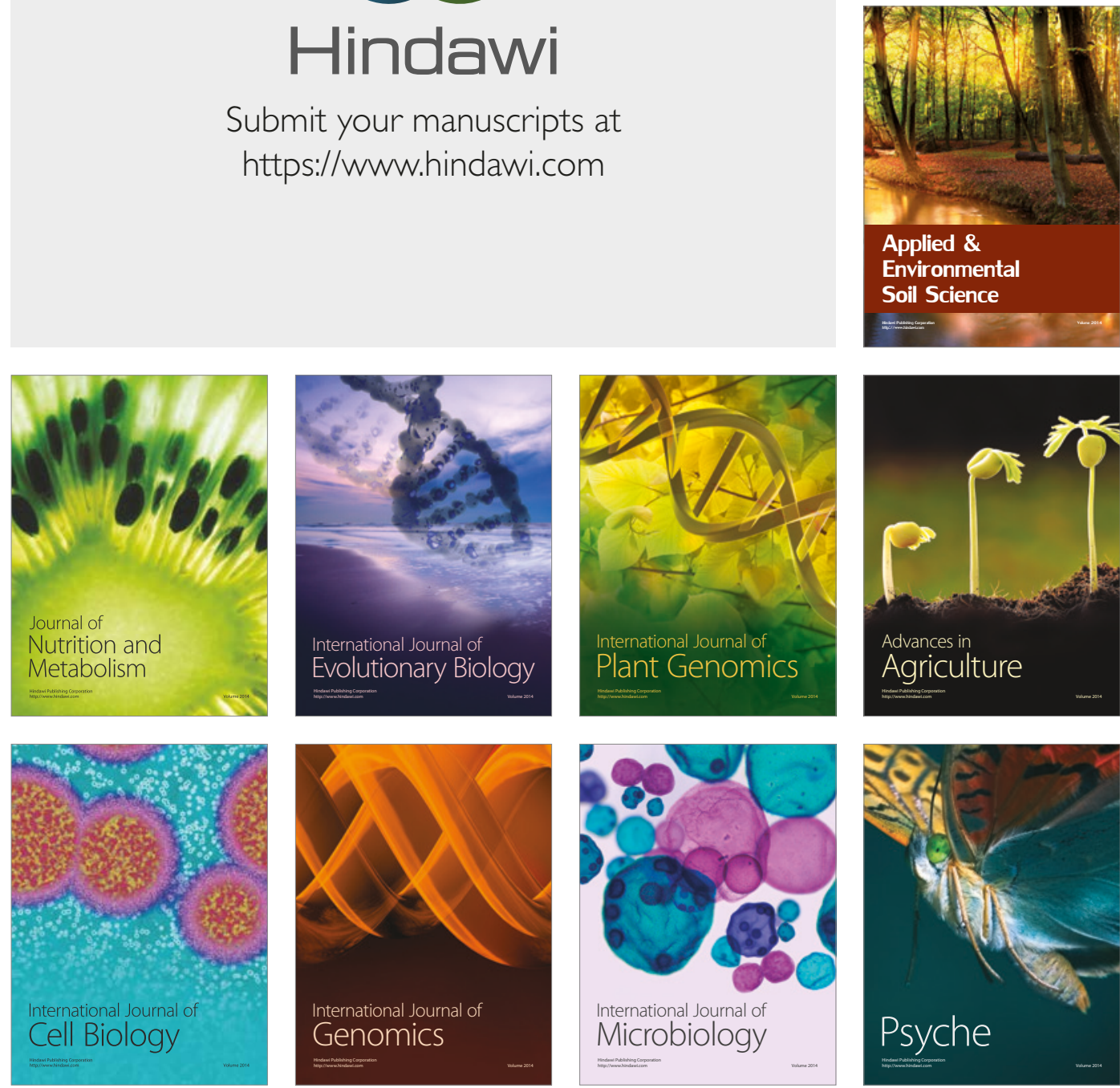

hternational Journal of Microbiology
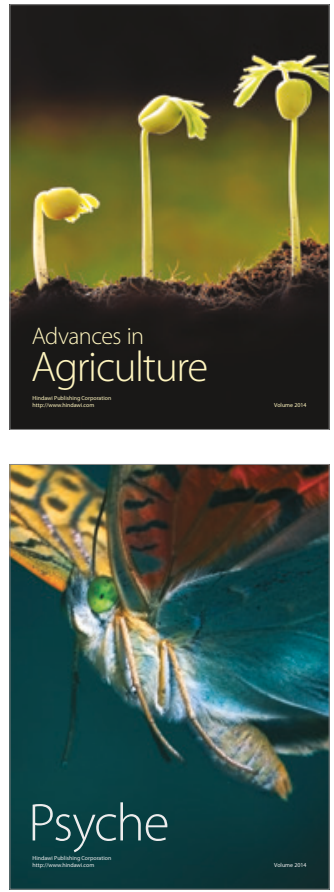